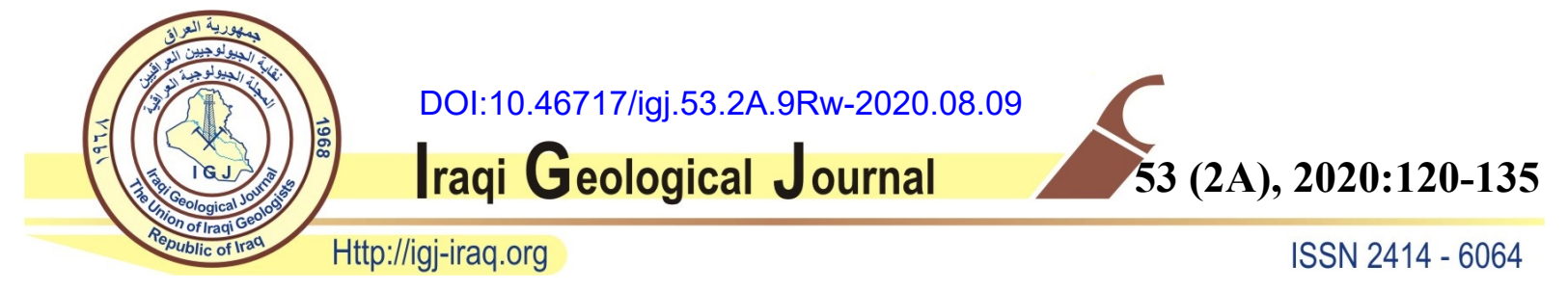

\title{
EVALUATION STRESS FIELD AND TECTONIC REGIME IN MID- EASTERN IRAQ-WESTERN IRAN FROM THE INVERSION OF MOMENT TENSOR FOCAL MECHANISM DATA
}

\author{
${ }^{1}$ Hasanain Jasim Mohammed ${ }^{*}$ and ${ }^{2}$ Ali M. Al-Rahim \\ ${ }^{1}$ Department of Seismology, Iraqi Meteorological Organization and Seismology, Baghdad, Iraq \\ ${ }^{2}$ Department of Geology, College of Science, University of Baghdad. Baghdad, Iraq \\ *E-mail: hjm82hjm82@yahoo.com \\ Received: 18 April 2020; accepted: 6 June 2020
}

\begin{abstract}
The estimation of the stress-field direction from focal mechanism of an earthquake is a pertinent tool to understand crustal mechanics and earthquake habit. The main aim of this study is to infer the stress pattern of the mid-eastern Iraq - western Iran region. The study area is situated between latitudes $33.59^{\circ}-34.93^{\circ} \mathrm{N}$ and longitudes $45.44^{\circ}-46.39^{\circ} \mathrm{E}$. Active stressed inversions of 102 moment tensor focal mechanisms data were used to rating the present day stress field. These data are subdivided into four regional subsets (circles) as a function of their geographical location and tectonic setting. The regional principal stress axes $(\sigma 1, \sigma 2$, and $\sigma 3)$ were inferred using right dihedron and rotational optimization methods by the formal stress inversion method. The results showed that there are spatial differences in the tectonic stress field, proportionate with fault orientations and faulting mechanisms. Thus, five stress regime categories are presented for the study area. It turns out that the prevailing tectonic systems are thrust faulting (50.98\%), strike-slip faulting (29.40\%), and unknown or oblique faulting (13.70\%); while the rest of the tectonic systems are less present thrust with strike-slip faulting (4.90\%), and normal with strike-slip faulting (0.98\%). The orientation of the maximum horizontal stress has a general directional trend towards $\mathrm{NW}$ SE and NE-SW with local deviations related to the main predominant geological structures. Quality stress classifications were determined for the four groups' areas and were of $B$ and C quality. The local extensional tectonic environment between strike-slip fault systems possibly it's the reason there are some normal faults. Finally, we note that the spatial differences of the tectonic regime and the stress field are compatible with the neotectonic stress field that is identified from focal mechanism data.
\end{abstract}

Keywords: Focal mechanism solutions; Moment stress axes; Stress inversion; Stress regimes 


\section{INTRODUCTION}

The analysis of the seismic source is one of the fundamental techniques in the study of active continental movements that can assist in determining the status and trends of tectonic movements and gives a better understanding of the current mode of tectonic deformation in the study region. It is possible to determine the stress that caused the faulting or seismic events through the classic stress inversion way, especially if there is a well-prepared homogeneous data (Angelier and Mechler, 1977; Angelier, 1984; Gephart and Forsyth, 1984).

The study area is located in the collision tectonics zones between the Arabian plate and the Iranian plate in the area between latitudes $33.59-34.93^{\circ} \mathrm{N}$ and longitudes $45.44-46.39^{\circ} \mathrm{E}$. The used data include earthquakes focal mechanisms with magnitudes $3.67 \leq \mathrm{MW} \leq 6.11$ that occurred in a seismically active region at the beginning of January 2018 to the end of August 2019 (102 events). Most of the events are located in mid-eastern Iraq and the western part of Iran; near to the borders and have depth ranged between $8-2 \mathrm{~km}$. The focal mechanisms data were taken from the study of Mohammed and Al-Rahim (2020) (Fig. 1). These data have chosen to assign the moment stress axes, horizontal stress axes and stress regimes (Table 1). The database available for the region of the study area was subdivided into four groups AA (BelulaEzgeleh), BB (Khanaqin-Qasre Shirin-Sarpol Zahab), CC (Mandali-Samoor), and DD (Qolqoleh-Halol) according to the spatial distribution of the events, the city names and the surrounding geographical locations (Fig.1).

A few studies were done to represent the paleo stress system in Iraq and surrounding regions. Abdulnaby et al. $(2014,2016)$ applied two methods to assess the orientations of the principal stress axes in Northern Iraq and Diyala city, respectively by using the formal stress inversion of fault plane solutions. The aims of this work are to give a comprehensive picture of the tectonic regime and determine the probable local variations of stress axis orientation using focal mechanisms stress inversion database computed for the region.

\section{TECTONIC FRAMEWORK}

The Arabian-Eurasian plates are colliding from the Zagros suture region in western Iran to the Bitlis suture zone in southern Turkey. This collision occurred under the control of various tectonic forces that had a clear impact on the recent tectonic framework and structural geology of Iraq during the Phanerozoic period (Abdulnaby, 2018). In recent active tectonic areas; the topography of the land surface is an accurate reflection of the underlying structure and its interaction with surface processes (Jackson et al., 1996). 


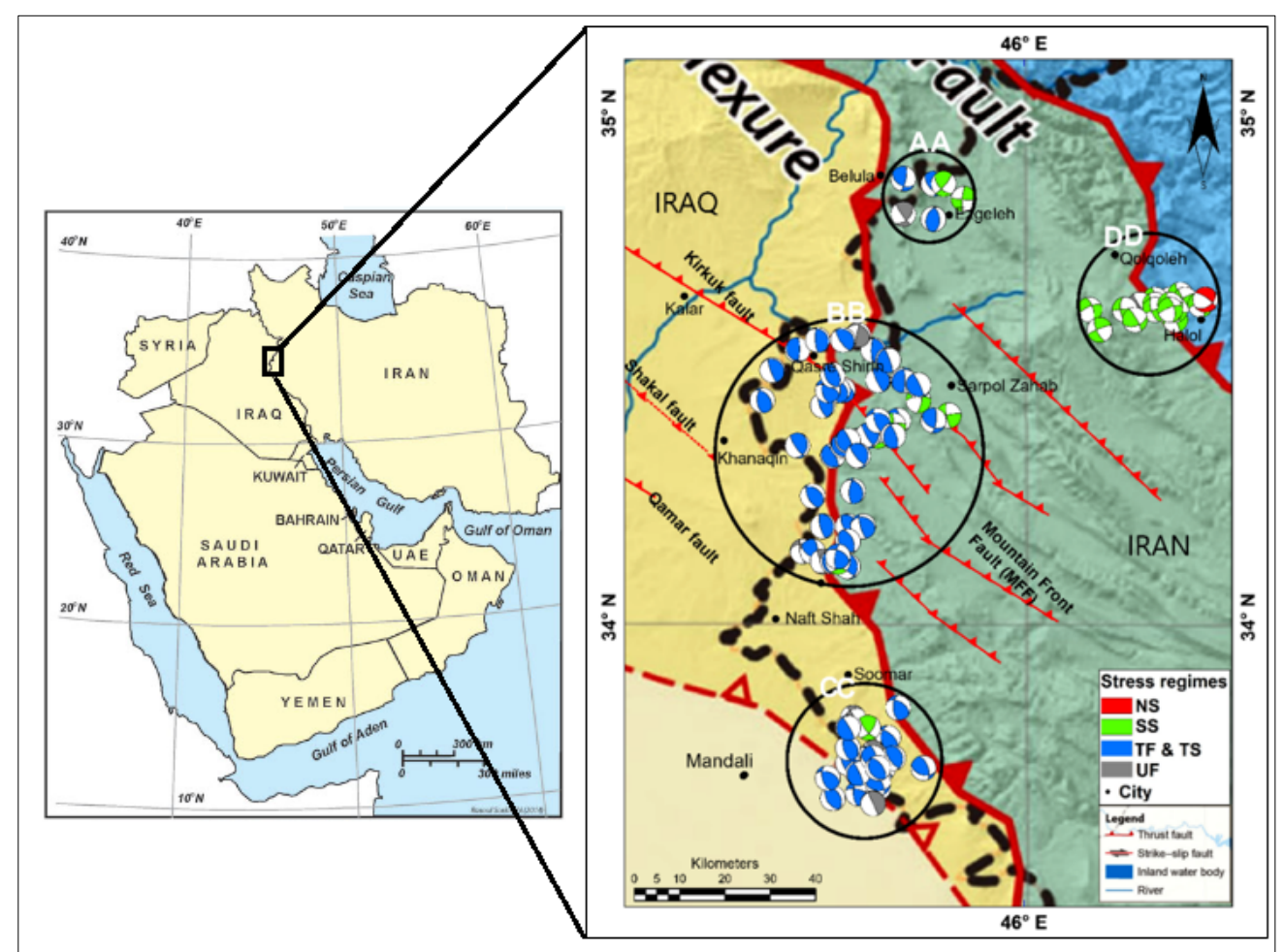

Fig.1. Colored map of focal mechanism for 102 events with main tectonic boundaries. Subdivided into four groups AA (Belula-Ezgeleh), BB (Khanaqin-Qasre Shirin-Sarpol Zahab), CC (Mandali-Samoor), and DD (Qolqoleh-Halol) according to (Mohammed and Al-Rahim, 2020)

Generally, the intensity of deformation, age of the sedimentary units and amount of shortening in the study region reduction from north and northeast (Zagros Suture Zone) in the direction of SW (Foreland region) (Fouad, 2014). Depending on the topography and deformational style, the northwestern and southeastern segments of the Zagros fold and thrust belt (including the study area) is one of the largest and most seismically active belts in the region, where it extends from eastern Turkey-Strait of Hormoz, (250-400) km wide (Khodaverdian et al., 2015). The topography of the high folded zone reflects high rugged "anticlinal" mountains discrete by deep and narrow "synclinal valleys because of the variation in resistance of diverse rock kinds to erosion and weathering (Fouad, 2014 and 2015; Sissakian et al., 2014). The seismicity of the area is due to the forces producing from movements of the Arabian plate to the north and northeast, which led to reactivation of the preexisting faults (Alridha et al., 2017).

The morphological units for the Zagros Fold-Thrust Belt is (i) Zagros suture zone, (ii) Imbricated zone, (iii) High folded zone, and (iv) Foothill zone (Fig. 2) (Jassim and Goff, 2006). The Zagros imbricate zone or known as the high Zagros zone in Iran is bounded by the main Zagros fault and main recent faults in the northeast and the high Zagros fault in the southwest 
(Alavi, 2004; Farzipour et al., 2009). The Zagros Imbricate Zone represents both the thrust and imbricate zones in the previous tectonic divisions of Iraq. The high folded zone is located between the high Zagros fault in the northeast and the mountain front fault in the southwest. This zone is known as a part of the Zagros simply folded zone in Iran (Alavi, 2004; Farzipour et al., 2009). The Foothill Zone has been divided by the Kirkuk Fault into the Chemchamal and the Hemrin subzone (Jassim and Goff, 2006). This zone is part of the Zagros simply folded zone in Iran too and bounded by the Mountain front fault in the northeast and the Zagros foredeep fault in the southwest (Mobasher, 2007).

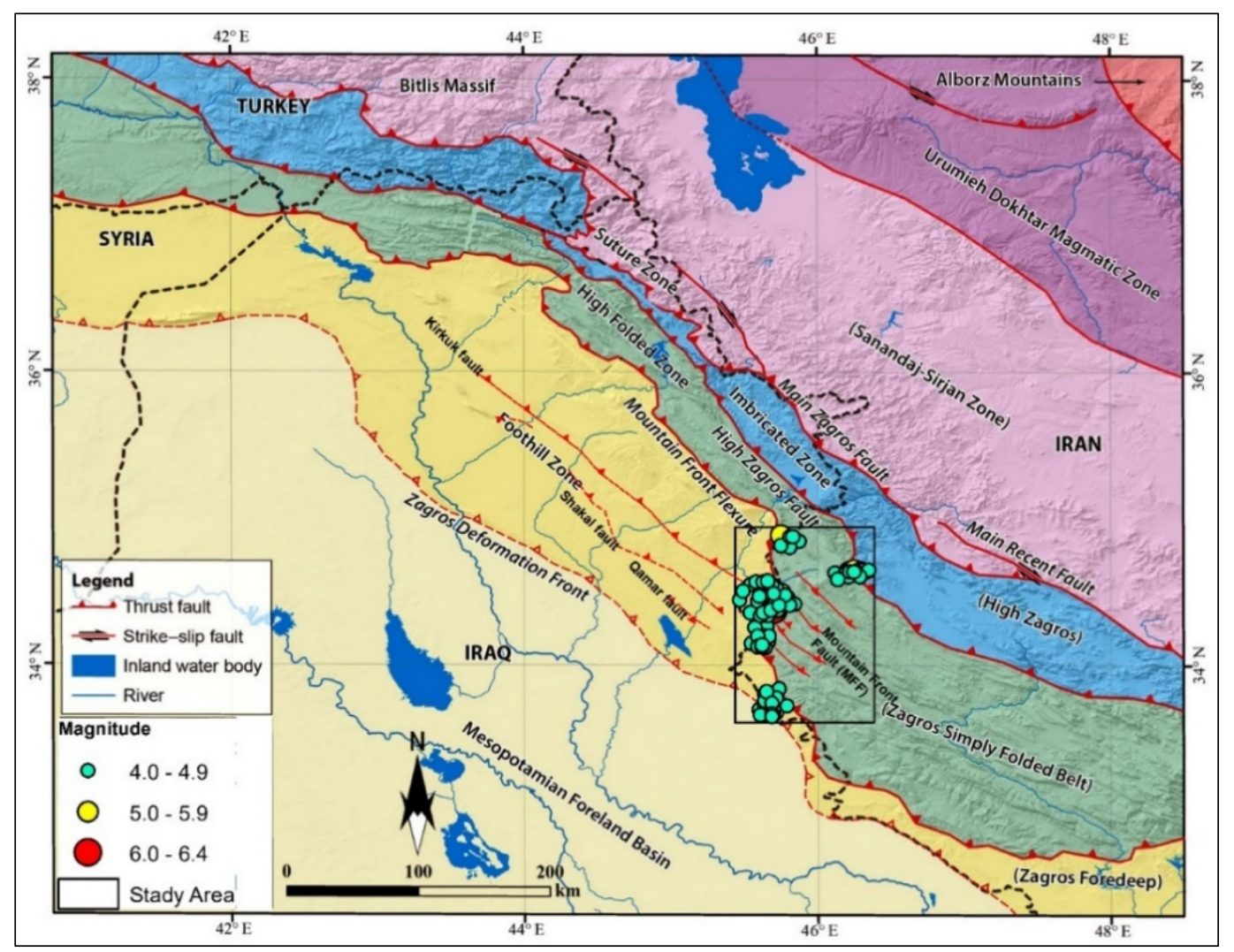

Fig. 2. Tectonic setting of mid-eastern Iraq - western part of Iran. Names within the parentheses are known in the Iranian part of Zagros (modified after Sissakian, 2000; Fouad, 2015; Zebari et al., 2019). The black rectangle represents the study area plotted in Fig. 1 and the magnitude of the 102 earthquakes is indicated by the diameter of the colored circles

\section{MATERIALS AND METHODS}

\section{Classification of Focal Mechanism Solutions}

Due to fault plane ambiguity, it is not known prior which of the two nodal planes of the focal mechanism is the rupture plane, thus; the moment stress axes (P, T, and N) are used as a proxy for the orientation of the principal stress axes (Barth et al., 2008). The fault plane solutions of 
the analyzed events are plotted using the (Frohlich, 1992) method and called Frohlich triangle diagram as in Fig. 3. The triangle diagram is generated using a computer code presented by (Hallo et al., 2019). The diagram uses the plunge of the $\mathrm{P}, \mathrm{T}$ and $\mathrm{N}$ axes of the focal mechanisms to determine their kind as revers or thrust, normal and strike-slip mechanism. Detailed information is listed in (Table 1) on the resulting focal mechanisms includes the strike orientation, dip angle, rake angle of both nodal planes, the trend of slip and the directions of the moment stress axes. The Frohlich ternary diagram is used to plot the data for each group with color-coding according to the focal mechanism kind: red for normal or with strike slip faulting, green for strike slip, blue for reverse pure or with strike slip faulting, and gray color for unknown or oblique type. The oblique type (odd) indicates the maximum horizontal stress azimuth is not defined. (Figs. 1 and 3) show the groups AA, BB, CC with a dominance of reverse fault, while the group DD they have a relatively strike-slip fault.

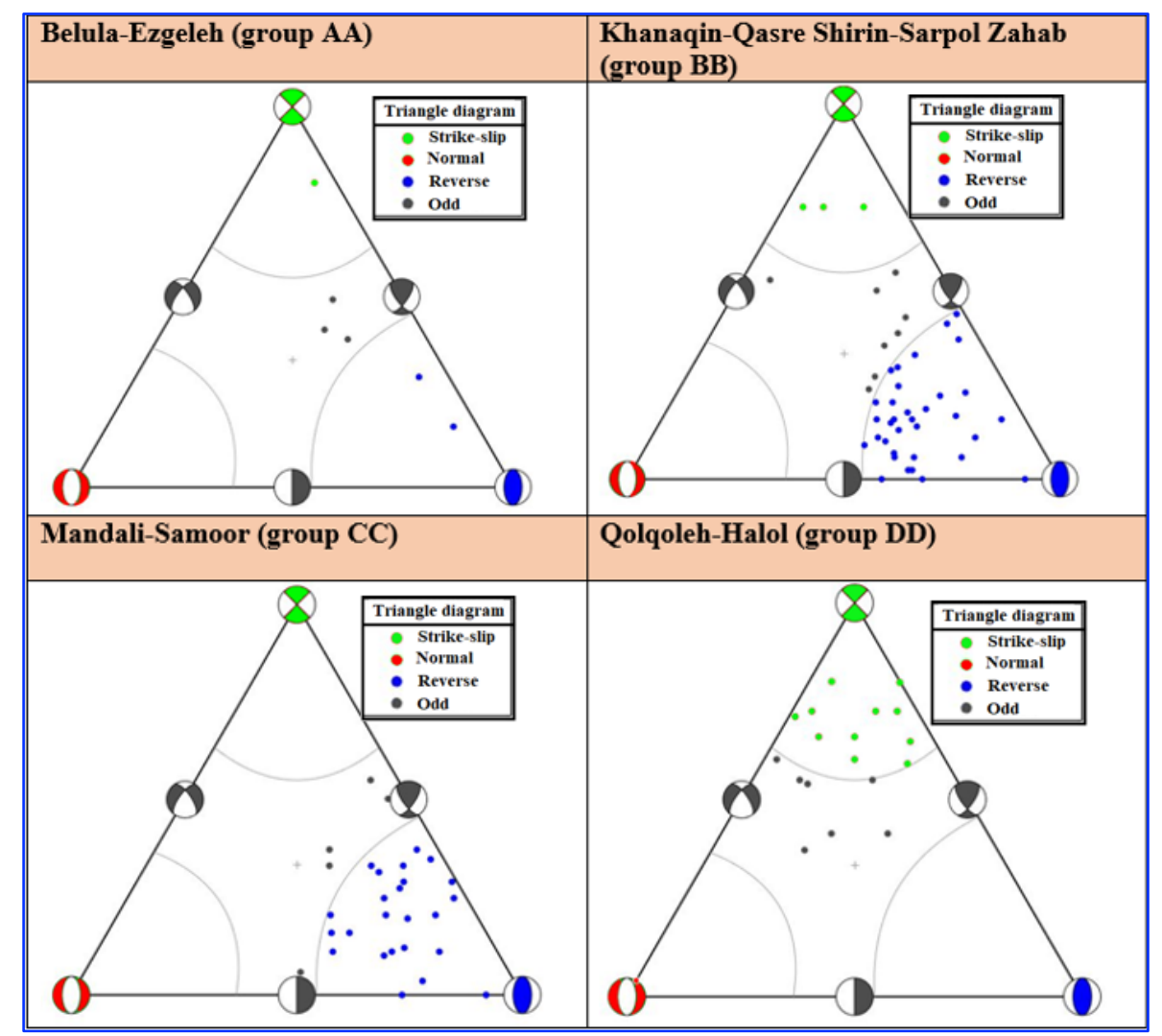

Fig. 3. Representation of the focal mechanisms data into four groups for stress inversion based on the Frohlich triangle diagram

\section{Moment Stress Axes}

The moment stress axes (P, N, and T) are respectively, maximum shortening, neutral axes and maximum extension. These axes are perpendicular to each other from both the fault and the auxiliary planes. From focal mechanisms; the moment stress axes for the seismic events differ mostly and do not correspond with principal stress axes $\sigma 1, \sigma 2$ and $\sigma 3$. This is due to 
earthquakes occurs on pre-existing faults (Scholtz, 2002; Stein and Wysession, 2003). Notwithstanding, $\sigma 1$ and $\sigma 3$ anticipants are located within the same quadrants such as $\mathrm{P}$ and $\mathrm{T}$ respectively. To derive the orientation of the $(\sigma 1, \sigma 2$ and $\sigma 3)$ from $(\mathrm{P}, \mathrm{N}$, and $\mathrm{T})$, a formal stress inversion way is needed to be performed (Delvaux and Sperner, 2003). The same is correct for principal stress axes $\sigma 1, \sigma 2$ and $\sigma 3$ only in state of new fracture generation in a homogeneous isotropic medium (Vavryčuk, 2014). A preliminary analysis was performed using all the moment stress axes of the focal mechanisms data in each group. The $\mathrm{P}$ axis at 45 degrees from the compressional dihedron (bisecting both focal planes) (Anderson, 1951). Table (1) shows moment stress axes relying on their azimuth (dip direction) and plunge (dip angle).

\section{Formal Stress Inversion Methods}

The determination directions of the faults must be accurate in a stress inversion step because using the wrong directions for the fault planes may output inexact results (Michael, 1984; Vavryčuk, 2014). The orientation of the three orthogonal principal stress axes $\sigma 1, \sigma 2$ and $\sigma 3$ forms most compressional to most dilatational, respectively with $\sigma 1 \geq \sigma 2 \geq \sigma 3 \geq 0$. The ratio of principal stresses:

$$
R=(\sigma 2-\sigma 3) / \sigma 1-\sigma 3)
$$

with $0 \leq R \leq 1$ is a measurement of the relative sizes of this principal stress. Wherefore, fault slip and focal mechanism data only constraint these four parameters that form the reduced stress tensor (Gephart and Forsyth., 1984; Angelier, 2002). In this research, two different formal stress inversion ways for the inversion of focal mechanisms are delineated using first: Right Dihedron method and second: Rotational Optimization Techniques (Delvaux and Sperner, 2003).

\section{The Right Dihedron method}

Right Dihedron method is utilized initially to process data, and this way was evolved by (Angelier and Mechler, 1977). The Rotational Optimization method uses the approximate and initial stress tensor as a starting point, which is an iterative process that aims to reduce the misfit function of each event.

\section{Rotational Optimization method}

This technique is the implementation of a new recurring inversion evolved by (Delvaux and Sperner, 2003). The purpose of this technique is to reduce a misfit function (using grid search) depending on the experiments for considerable number of different stress tensors. A statistical procedure is applied to compute $(\sigma 1, \sigma 2$ and $\sigma 3)$ for the trust areas to invents different sets of fault planes and to see the general probable stress tensor in the area. In each focal mechanism 
two, nodal planes (fault and the auxiliary) are inverted to a stress tensor. Now, the factual fault plane will be based on the plane that has the least value of the misfit from both nodal planes. After this separation, only the selected fault planes will be inverted to calculate the $(\sigma 1, \sigma 2, \sigma 3$ and R) (Gephart and Forsyth, 1984). The consequences will be represented on an equal-area projection to assist with appraising the total quality of the outcome.

\section{Horizontal stress axes method}

The exact orientations of the horizontal stress are usually expressed the maximum $\left(S H_{\text {MAX }}\right)$ and the minimum $\left(\mathrm{SH}_{\mathrm{min}}\right)$ horizontal stress axis respectively. These are always perpendicular to each other. There are two ways to calculate, the first represented from the moment stress axes (Zoback, 1992a). While the second method is to compute the horizontal stress axes from the principal stress directions with a ratio of principal stresses $(\sigma 1, \sigma 2$ and $\sigma 3$ and $\mathrm{R})$ that are acquired from the inversion of fault plane solutions data (Lund and Townend., 2007) and applied in the windows-tensor program, in this study.

\section{Evaluation of Stress Tensor Qualities}

The Global Stress Map (WSM) is a global collection of data resources about the crustal presentday stress domain preserve. This map is utilized to assess the quality of our results in (GFZ) German Research Centre for Geosciences at the Helmholtz Potsdam Center. Heidbach et al. (2016) identified the quality ranking scheme for formal inversion of the focal mechanisms. The scheme is fundamentally based on the number, the precision, and the deep of the observation. The quality of each stress data record is set between $\mathrm{A}$, and $\mathrm{E}$, starting with higher quality $\mathrm{A}$, and, lowest E. Quality A, intended that the orientation of $S H_{M A X}$ is precise to within \pm 15 , while, quality $\mathrm{B}$, to within \pm 20 . Whereas, the quality $\mathrm{C}$ to within the limits \pm 25 , and finally D quality to within the limits \pm 40 . Generally, most of the ways quality categories are determined via the standard deviation of $S_{M A X}$. If the data records are of type (E) quality that has standard deviations greater than 40 , then they do not provide sufficient information for those records. Heidbach (2016) considered the reliability of type A, B and C quality stress indexes to be utilized in the exegesis of geodynamic processes and in stress patterns resolving.

\section{Tectonic stress regimes $\left(R^{\prime}\right)$}

The basic concept of the stress regime index $R^{\prime}$, as described by (Delvaux et al, 1997; Delvaux and Sperner, 2003) is used as a numerical expression of the stress regime, based on the value of the stress ratio $(R)$, and known as follows:

$R_{N F}^{\prime}=R$ for extensional stress regime or normal faulting regimes (NF)

$R_{S S}^{\prime}=(2-R)$ for strike-slip regimes (SS) 
$R_{T F}^{\prime}=(2+R)$ for compressional stress regime or thrust faulting regimes (TF).

Tectonic stresses form a continual scale. In normal regimes, the value of the indicator $R^{\prime}$ ranges from 0 to 1 , whereas for strike-slip regimes it is 1 to 2 , and 2 to 3 for compression regimes (Delvaux et al., 1997), as well as their types according to the (WSM) project standard (NF, SS and TF refer to normal, strike-slip and thrust faulting, while NS: intermediate between NF and SS, TS: intermediate between SS and TF, UF: unknown or oblique (Zoback, 1992b; Heidbach et al., 2010).

\section{RESULTS}

\section{Horizontal Stress Axes Results}

The orientation of $S H_{M A X}$ outcomes reveals a general trend of northwestern-southeastern to northeastern-southwestern with local perversions related to the big geological structures. Detailed results are obtained were identical in most cases using windows-tensor program to analyze the 102 focal mechanisms. The compression stress system at the Zagros fold and the thrust zone have a perpendicular direction near the Iraq-Iran border, as shown by the directions of the horizontal stress axes. Table (1) and Fig. 4 show the orientations of the horizontal stress axes.

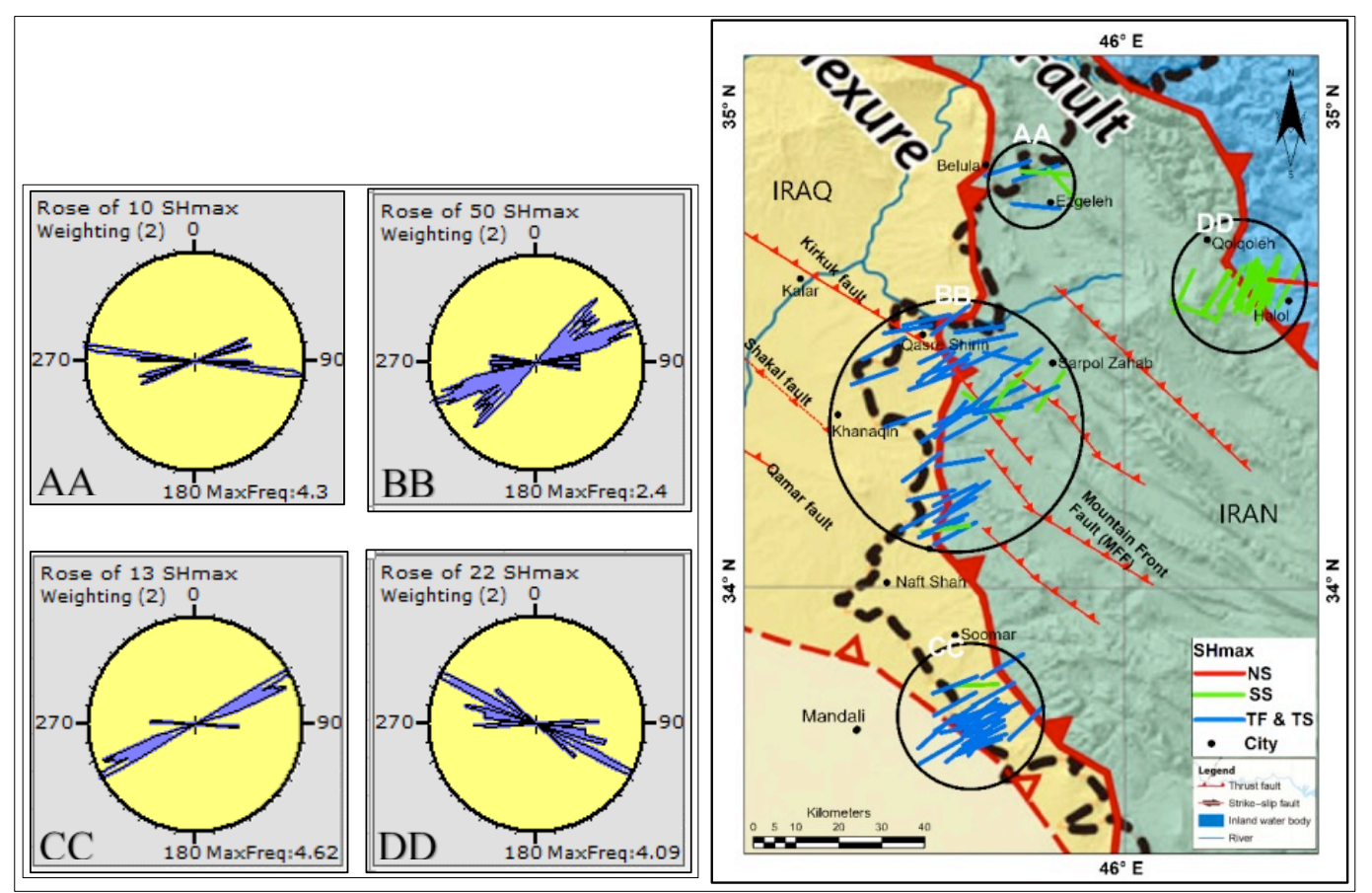

Fig. 4. (Left) Rose diagrams show the direction of the maximum horizontal stress axis $\left(S_{M A X}\right)$ from the formal stress inversion methods in each group based on Table (2). (Right) $S H_{M A X}$ from the focal mechanism database shown in Table (1) following the convention of Zoback (1992a). The lines colors indicate the type of faulting: red for normal; blue for thrust; and green for strike-slip 


\section{Tectonic Stress Regimes Results}

Based on Zoback, (1992 a \& b) it has been evaluated tectonic stress regime for each focal mechanism in the region (Table 1). Fig. 5 shows the distribution of five categories stress regimes existing in the current study. However, the TF (50.98 \%), SS (29.40\%), and UF (13.70 $\%)$ are the most common tectonic systems, while, the less recurrent stress regimes in the region are TS $(4.90 \%)$ and NS $(0.98 \%)$.

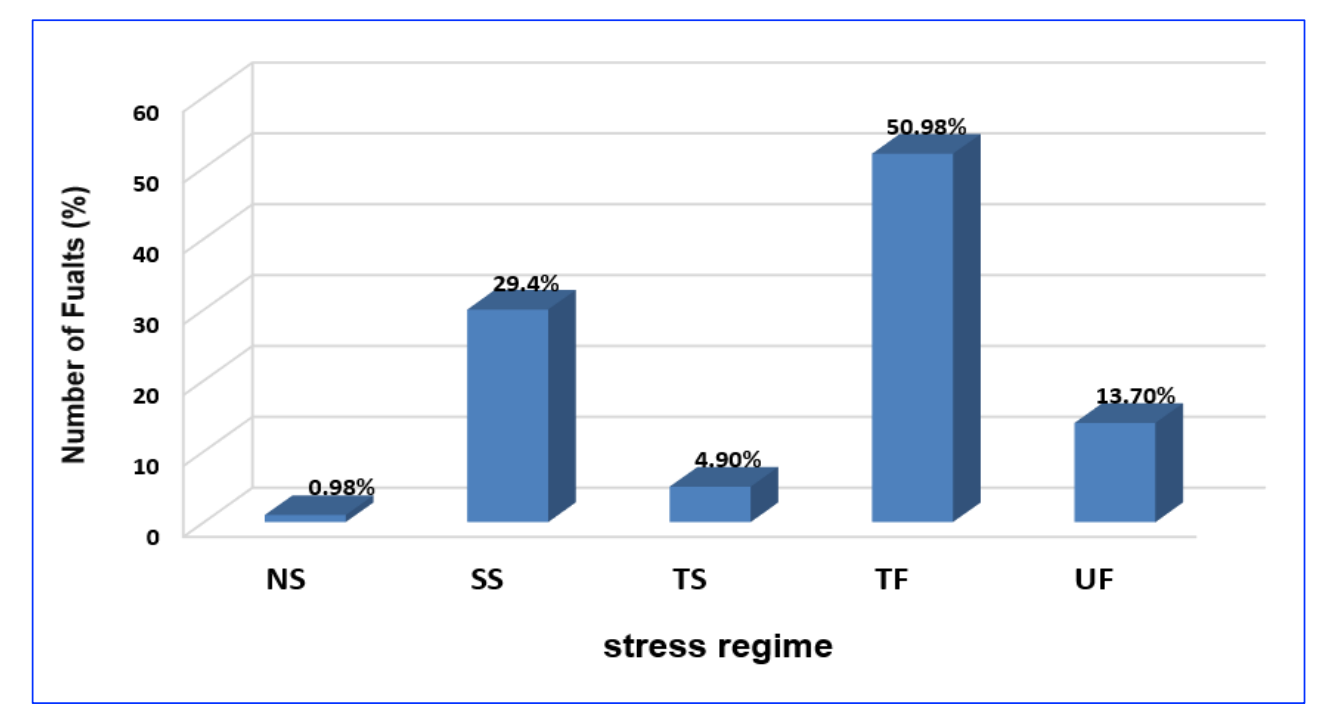

Fig. 5. Apportionment categories of stress regimes from focal mechanism data existing in the study area

\section{Formal Stress Inversion Results}

The study area was divided into four regional subsets (circles). The stress inversion for all focal mechanism within each circle is studied separately using New Right Dihedron with Rotational Optimization ways. Fig. 6 represents the results of the stress inversion in the form of graphical outputs using Win-tensor. The projection of the $\sigma 1, \sigma 2$ and $\sigma 3$ in a lower-hemisphere equalarea stereographic projection plot of the chosen focal planes as it is shown in cyclograph trace. If the normal faulting, it will be slip lines as a black dot with the external arrow, while reverse faulting is inside arrow, and strike-slip faulting is double semi-arrows. The orientation of the $\sigma 1$ is as a turquoise point encompassed by a circle, while $\sigma 2$ is as a triangle and a square for $\sigma 3$. Large arrows outside the stereogram illustrate the related $S H_{M A X}$ and $S H_{\min }$ orientations. The big blue arrow represents outside the stereogram is $S H_{M A X}$, while a red arrow for $S H_{\text {min }}$. The black bars on the periphery of the stereogram for the $S H_{M A X}$, while, white bars symbolize the directions of the horizontal stress axes for $\mathrm{SH}_{\min }$ for unique focal mechanisms. 
Table 1. Source parameters from (Iranian seismological center catalog), and focal mechanism solution of moment tensor inversion were taken (Mohammed and Al-Rahim, 2020) used for formal stress inversion in this study

\begin{tabular}{|c|c|c|c|c|c|c|c|c|c|c|c|c|}
\hline & & & & & & & & & & & & \\
\hline Event Date & $\begin{array}{l}\text { O. Time } \\
\text { (UTC) }\end{array}$ & Lat. E & Log. $\mathrm{N}$ & CD & MW & S & Plane & & & lane & & \\
\hline $2018 / 01 / 05$ & 6.32 .57 & 34530 & 45608 & 19 & 400 & $\frac{\mathrm{s}}{181}$ & D & $\mathrm{K}$ & $\frac{5}{325}$ & D & $\mathrm{K}$ & PL \\
\hline $2018 / 01 / 06$ & $15: 22: 08$ & $\begin{array}{l}34.030 \\
34.471\end{array}$ & 45.759 & 17 & 5.02 & $\frac{101}{360}$ & 80 & 75 & 237 & 18 & 146 & $\frac{32}{33}$ \\
\hline $2018 / 01 / 11$ & $6: 59: 29$ & 33.712 & 45.693 & 20 & 5.63 & 135 & 65 & 70 & 356 & 32 & 126 & 18 \\
\hline $2018 / 01 / 11$ & $7: 00: 53$ & 33.667 & 45.714 & 16 & 5.28 & 166 & 54 & 110 & 315 & 40 & 65 & 07 \\
\hline $2018 / 01 / 11$ & $7: 14: 15$ & 33.722 & 45.709 & 18 & 5.28 & 160 & 65 & 90 & 340 & 25 & 90 & 20 \\
\hline $2018 / 01 / 11$ & $7: 21: 33$ & 33.700 & 45.719 & 19 & 5.27 & 315 & 75 & 75 & 181 & 21 & 134 & 28 \\
\hline $2018 / 01 / 11$ & $7: 37: 09$ & 33.762 & 45.731 & 21 & 4.02 & 310 & 60 & 60 & 179 & 41 & 131 & 10 \\
\hline $2018 / 01 / 11$ & $7: 52: 47$ & 33.815 & 45.747 & 17 & 4.11 & 177 & 57 & 130 & 300 & 50 & 45 & 4 \\
\hline $2018 / 01 / 11$ & $7: 55: 00$ & 33.733 & 45.703 & 18 & 4.80 & 150 & 80 & 70 & 34 & 22 & 153 & 32 \\
\hline $2018 / 01 / 11$ & $8: 00: 39$ & 33.724 & 45.686 & 18 & 5.28 & 167 & 67 & 99 & 325 & 25 & 70 & 21 \\
\hline $2018 / 01 / 11$ & $8: 17: 55$ & 33.641 & 45.622 & 17 & 3.98 & 150 & 50 & 90 & 330 & 40 & 90 & 5 \\
\hline $2018 / 01 / 11$ & $8: 29: 03$ & 33.804 & 45.659 & 18 & 3.82 & 330 & 80 & 50 & 228 & 41 & 165 & 24 \\
\hline $2018 / 01 / 11$ & $9: 23: 55$ & 33.677 & 45.706 & 19 & 3.90 & 130 & 65 & 65 & 358 & 35 & 132 & 16 \\
\hline $2018 / 01 / 11$ & $9: 32: 24$ & 33.706 & 45.653 & 18 & 4.12 & 155 & 55 & 100 & 318 & 36 & 76 & 9 \\
\hline $2018 / 01 / 11$ & $13: 16: 43$ & 33.724 & 45.735 & 18 & 4.21 & 145 & 65 & 80 & 348 & 27 & 110 & 19 \\
\hline $2018 / 01 / 11$ & $13: 30: 46$ & 33.740 & 45.654 & 17 & 3.91 & 165 & 60 & 109 & 310 & 35 & 60 & 13 \\
\hline $2018 / 01 / 11$ & 14:47:17 & 33.723 & 45.699 & 20 & 4.01 & 330 & 80 & 55 & 226 & 36 & 163 & 27 \\
\hline $2018 / 01 / 11$ & $20: 19: 40$ & 33.653 & 45.697 & 18 & 3.81 & 168 & 62 & 101 & 325 & 30 & 70 & 16 \\
\hline $2018 / 01 / 11$ & $21: 50: 44$ & 33.775 & 45.685 & 19 & 4.31 & 140 & 70 & 30 & 39 & 62 & 157 & 5 \\
\hline $2018 / 01 / 11$ & $21: 52: 22$ & 33.779 & 45.648 & 20 & 3.77 & 330 & 80 & 80 & 195 & 14 & 135 & 34 \\
\hline $2018 / 01 / 12$ & $17: 50: 40$ & 33.645 & 45.671 & 16 & 3.88 & 285 & 65 & 35 & 179 & 59 & 150 & 4 \\
\hline$\frac{2010 / 1 / 12}{2018 / 01 / 13}$ & $\frac{1: 30.40}{0: 33: 26}$ & $\frac{35.043}{33.660}$ & $\begin{array}{l}43.0 / 1 \\
45.708\end{array}$ & $\frac{10}{19}$ & $\frac{3.00}{4.27}$ & $\frac{203}{140}$ & $\frac{03}{50}$ & $\frac{35}{60}$ & $\frac{179}{2}$ & 48 & $\frac{150}{121}$ & $\frac{4}{1}$ \\
\hline $2018 / 01 / 13$ & $6: 30: 30$ & 33.671 & 45.707 & 17 & 3.81 & 332 & 66 & 123 & 95 & 40 & 40 & 14 \\
\hline $2018 / 01 / 13$ & 9:3:54:19 & 33.718 & 45.699 & 19 & $\frac{3.01}{4.21}$ & $\frac{532}{140}$ & 50 & 65 & 356 & 46 & $\frac{40}{117}$ & $\frac{14}{2}$ \\
\hline $2018 / 01 / 14$ & $19: 45: 47$ & 34.396 & 45.851 & 17 & 4.11 & 260 & 85 & 15 & 169 & 75 & 175 & 7 \\
\hline $2018 / 01 / 18$ & $16: 48: 42$ & 34.556 & 45.669 & 15 & 3.92 & 192 & 82 & 114 & 300 & 25 & 20 & 33 \\
\hline $2018 / 01 / 19$ & $22: 17: 56$ & 33.709 & 45.699 & 16 & 4.91 & 333 & 61 & 118 & 105 & 40 & 50 & 11 \\
\hline$\frac{2018 / 11 / 9}{2018 / 01 / 21}$ & $\frac{22: 1: 50}{2: 19: 37}$ & $\frac{30.09}{34.528}$ & $\begin{array}{l}43.099 \\
45.547\end{array}$ & $\frac{10}{14}$ & $\begin{array}{l}4.91 \\
4.03 \\
\end{array}$ & $\frac{303}{2}$ & $\frac{01}{76}$ & $\frac{118}{104}$ & $\frac{103}{135}$ & $\frac{40}{20}$ & $\frac{50}{45}$ & $\frac{11}{30}$ \\
\hline $2018 / 01 / 21$ & $5: 45: 39$ & 34.548 & 45.586 & 16 & 4.05 & 177 & 74 & 102 & 320 & 20 & 55 & 28 \\
\hline $2018 / 01 / 26$ & $\frac{0.4 .39}{20: 17: 34}$ & $\begin{array}{l}34.040 \\
33.675 \\
\end{array}$ & $\begin{array}{l}45.500 \\
45.611\end{array}$ & 13 & $\begin{array}{l}4.03 \\
4.09\end{array}$ & 163 & 54 & 127 & 290 & 50 & $\frac{53}{50}$ & $\frac{20}{2}$ \\
\hline $2018 / 02 / 02$ & $9: 42: 57$ & 34.798 & 45.757 & 8 & 4.16 & 145 & 80 & 45 & 45 & 46 & 166 & 22 \\
\hline $2018 / 02 / 16$ & 18:22:00 & 33.634 & 45.699 & 18 & 3.97 & 155 & 89 & 95 & 255 & 5 & 10 & 44 \\
\hline $2018 / 03 / 28$ & $0: 27: 05$ & 34.491 & 45.497 & 19 & 3.95 & 161 & 78 & 99 & 305 & 15 & 55 & 32 \\
\hline $2018 / 04 / 01$ & $8: 35: 25$ & 34.434 & 45.786 & 15 & 5.13 & 08 & 69 & -148 & 265 & 60 & -25 & 38 \\
\hline $2018 / 04 / 02$ & 3:03:22 & 34.388 & 45.821 & 14 & 4.01 & $\frac{18}{7}$ & 73 & 132 & 115 & 45 & 25 & $\frac{17}{17}$ \\
\hline$\frac{2010 / 8 / 04 / 30}{2018}$ & $\frac{1.03 .22}{22: 14: 49}$ & $\begin{array}{l}34.000 \\
34.861\end{array}$ & $\begin{array}{l}\frac{43.021}{45.821} \\
\end{array}$ & 18 & 4.015 & 140 & 55 & 60 & $\frac{11}{5}$ & $\frac{73}{45}$ & 126 & $\frac{17}{6}$ \\
\hline $2018 / 05 / 22$ & $0: 31: 53$ & 34.830 & 45.879 & 16 & 4.35 & 94 & 85 & 170 & 185 & 80 & 5 & 4 \\
\hline $2018 / 06 / 26$ & $17: 57: 03$ & 34.618 & 46.268 & 15 & 4.54 & 255 & 85 & 15 & 164 & 75 & 175 & 7 \\
\hline $2018 / 06 / 26$ & $22: 13: 05$ & 34.546 & 45.641 & 14 & 3.77 & 146 & 71 & 95 & 310 & 20 & 75 & 26 \\
\hline $2018 / 07 / 15$ & $7: 10: 59$ & 34.614 & 46.278 & 17 & 4.32 & 245 & 90 & 20 & 155 & 70 & 180 & 14 \\
\hline $2018 / 07 / 16$ & $5: 33: 53$ & 34.625 & 46.289 & 14 & 4.16 & 133 & 81 & -160 & 40 & 70 & -10 & 21 \\
\hline $2018 / 07 / 22$ & $10: 07: 25$ & 34.630 & 46.255 & 15 & 5.52 & 343 & 80 & -165 & 250 & 75 & -10 & 18 \\
\hline $2018 / 07 / 22$ & $16: 48: 47$ & 34.585 & 46.296 & 13 & 3.98 & 337 & 86 & -150 & 245 & 60 & -5 & 24 \\
\hline $2018 / 07 / 23$ & $0: 59: 47$ & 34.606 & 46.303 & 16 & 4.37 & 156 & 85 & -170 & 65 & 80 & -5 & 11 \\
\hline $2018 / 07 / 24$ & $8: 46: 11$ & 34.643 & 46.312 & 16 & 4.29 & 158 & 80 & 170 & 250 & 80 & 10 & 0 \\
\hline $2018 / 07 / 24$ & $\begin{array}{l}19: 58: 29 \\
\end{array}$ & 34.794 & 45.816 & 14 & 4.50 & 355 & 50 & 75 & 197 & 42 & 107 & 4 \\
\hline $2018 / 07 / 25$ & $1: 47: 47$ & 34.634 & 46.315 & 17 & 4.02 & 147 & 80 & 165 & 240 & 75 & 10 & 4 \\
\hline $2018 / 07 / 26$ & $15: 51: 19$ & 34.317 & 45.622 & 17 & 4.15 & 331 & 76 & 96 & 125 & 15 & 65 & 31 \\
\hline $2018 / 08 / 04$ & $17: 02: 04$ & 34.620 & 46.354 & 12 & 3.75 & 344 & 76 & -164 & 250 & 75 & -15 & 21 \\
\hline $2018 / 08 / 25$ & $22: 13: 25$ & 34.622 & 46.233 & 13 & 5.82 & 250 & 75 & -30 & 348 & 61 & -162 & 45 \\
\hline$\frac{2010 / 808 / 25}{2018 / 08}$ & $\frac{2.11 .25}{5: 18: 28}$ & $\begin{array}{l}34.022 \\
34.622\end{array}$ & 40.2331 & $\frac{13}{16}$ & $\frac{3.02}{4.05}$ & $\frac{50}{147}$ & 83 & $\frac{-50}{-135}$ & $\frac{340}{50}$ & $\frac{01}{45}$ & $\frac{-102}{-10}$ & $\frac{45}{36}$ \\
\hline $2018 / 08 / 26$ & $8: 25: 03$ & 34.620 & 46.259 & 11 & 3.67 & 153 & 77 & -149 & 55 & 60 & -15 & 31 \\
\hline $2018 / 08 / 26$ & $\begin{array}{l}0.25 .03 \\
9: 23: 33 \\
\end{array}$ & 34.608 & 46.202 & 12 & 3.67 & 159 & 76 & 154 & 255 & 65 & $\frac{13}{15}$ & 8 \\
\hline $2018 / 08 / 29$ & $5: 34: 35$ & 34.613 & 46.291 & 11 & 4.12 & 164 & 76 & -164 & 70 & 75 & -15 & 21 \\
\hline $2018 / 08 / 31$ & $21: 05: 43$ & 34.608 & 46.127 & 13 & 4.73 & 245 & 70 & -25 & 344 & 67 & -158 & 32 \\
\hline $2018 / 09 / 01$ & $5: 31: 10$ & 34.344 & 40.127 & 16 & 4.17 & $\frac{24 J}{145}$ & 75 & 70 & 20 & 25 & $\frac{-150}{142}$ & $\frac{32}{27}$ \\
\hline$\frac{2018(10901 / 09}{2018 / 09}$ & $\frac{3: 31: 10}{23: 53: 54}$ & $\begin{array}{l}34.344 \\
34.455\end{array}$ & $\begin{array}{l}45.543 \\
45.794\end{array}$ & $\frac{10}{16}$ & $\frac{4.17}{3.78}$ & $\frac{145}{335}$ & $\frac{15}{80}$ & $\frac{10}{100}$ & $\frac{20}{110}$ & $\frac{25}{14}$ & $\frac{142}{45}$ & $\frac{21}{34}$ \\
\hline $2018 / 09 / 13$ & 17:05:10 & 34.612 & 46.195 & 14 & 3.80 & 265 & 85 & 30 & 172 & 60 & 174 & 17 \\
\hline $2018 / 09 / 19$ & 19:29:19 & 34.6093 & $\begin{array}{l}40.195 \\
45.673\end{array}$ & $\frac{14}{17}$ & $\frac{3.00}{4.13}$ & $\frac{205}{335}$ & $\frac{03}{80}$ & $\frac{50}{75}$ & $\frac{112}{212}$ & $\frac{00}{18}$ & 146 & 33 \\
\hline $2018 / 09 / 30$ & $23: 49: 24$ & 34.609 & 46.255 & 16 & 4.13 & 250 & 90 & 25 & 160 & 65 & 180 & 17 \\
\hline $2018 / 10 / 17$ & $03: 16:$ & 34.43 & 45.4 & 18 & 4.76 & 177 & 56 & 113 & 320 & 40 & 60 & 09 \\
\hline $2018 / 11 / 05$ & $20: 32: 07$ & 34.618 & 46.285 & 16 & 4.14 & 165 & 76 & 159 & $\frac{200}{260}$ & 70 & 15 & 04 \\
\hline $2018 / 11 / 17$ & 19:19:03 & 34.609 & 46.293 & 13 & 4.15 & 250 & 75 & -30 & 348 & 61 & -163 & 32 \\
\hline $2018 / 11 / 19$ & $\frac{1.10 .03}{22: 37: 41}$ & 34.566 & 46.145 & 17 & 4.13 & 248 & 81 & -160 & 255 & 70 & -10 & $\frac{32}{21}$ \\
\hline$\frac{20101111 / 19}{2018 / 11 / 25}$ & $\begin{array}{l}2.2 .3: 41 \\
16: 37: 31\end{array}$ & $\begin{array}{l}34.000 \\
34.359\end{array}$ & $\frac{40.14}{45.71}$ & $\frac{11}{20}$ & $\begin{array}{ll}4.03 \\
6.11\end{array}$ & $\frac{240}{135}$ & $\frac{01}{80}$ & $\begin{array}{l}-100 \\
-15\end{array}$ & $\frac{253}{228}$ & 75 & $\frac{-10}{-170}$ & $\frac{21}{18}$ \\
\hline $2018 / 11 / 25$ & $16: 41: 11$ & 34.372 & 45.707 & 15 & 4.75 & 355 & 80 & 35 & 258 & 56 & 168 & 16 \\
\hline $2018 / 11 / 25$ & $17: 09: 36$ & 34.348 & 45.665 & 15 & 4.97 & 175 & 84 & 98 & 305 & 10 & 40 & 38 \\
\hline $2018 / 11 / 25$ & 17:21:05 & 34.342 & 45.636 & 18 & 4.05 & 316 & 71 & 95 & 120 & 20 & 75 & 26 \\
\hline $2018 / 11 / 25$ & $17: 26: 59$ & 34.359 & 45.688 & 16 & 3.99 & 150 & 80 & 75 & 27 & 18 & 146 & 33 \\
\hline $2018 / 11 / 25$ & $\begin{array}{l}17: 20.59 \\
17: 31: 19\end{array}$ & 34.388 & $\begin{array}{l}45.000 \\
45.747\end{array}$ & 19 & 3.98 & 348 & $\frac{00}{71}$ & 107 & 125 & 25 & $\frac{140}{50}$ & $\frac{35}{24}$ \\
\hline $2018 / 11 / 25$ & $20: 42:$ & 34.1 & 45.6 & 16 & 3.93 & 150 & 60 & 85 & 340 & 30 & 99 & 15 \\
\hline $2018 / 11 / 25$ & $20: 56: 38$ & 34.177 & 45.602 & 14 & 4.13 & 165 & 73 & 88 & 351 & 17 & 96 & 21 \\
\hline $2018 / 11 / 25$ & $23: 00: 46$ & 34.246 & 45.659 & 15 & 4.20 & 184 & 66 & 108 & 325 & 30 & 55 & 19 \\
\hline $2018 / 11 / 26$ & $0: 38: 36$ & 34.379 & 45.742 & 19 & 5.04 & 356 & 85 & -165 & 265 & 75 & -05 & 14 \\
\hline $2018 / 11 / 26$ & $1: 19: 42$ & 34.349 & 45.654 & 20 & 4.43 & 336 & 76 & 95 & 135 & 15 & 70 & 31 \\
\hline $2018 / 11 / 27$ & $\frac{1.19 .42}{6: 36: 34}$ & $\frac{34.3}{34.3}$ & $\frac{45.0}{45.7}$ & 19 & $\begin{array}{l}4.43 \\
4.19 \\
\end{array}$ & $\frac{350}{162}$ & 68 & 125 & $\frac{153}{280}$ & 40 & 35 & $\frac{31}{16}$ \\
\hline $2018 / 11 / 27$ & $23: 50:$ & 34.32 & 45.6 & 20 & 4.1 & 140 & 75 & 75 & 06 & 21 & 134 & 28 \\
\hline $2018 / 11 / 29$ & $13: 16: 23$ & 34.175 & 45.682 & 18 & 3.90 & 164 & 73 & 115 & 285 & 30 & 35 & 24 \\
\hline $2018 / 12 / 09$ & $3: 24: 11$ & 34.364 & 45.744 & 13 & 4.32 & 340 & 70 & 75 & 198 & 25 & 125 & 24 \\
\hline $2018 / 12 / 27$ & $22: 57: 02$ & 34.468 & 45.712 & 15 & 3.79 & 155 & 80 & 90 & 335 & 10 & 90 & 35 \\
\hline $2019 / 01 / 06$ & 13:41: & 34.151 & $\frac{45.14}{4564}$ & 16 & $\frac{1.17}{571}$ & 337 & 56 & 100 & 135 & 35 & 75 & $\frac{11}{11}$ \\
\hline $2019 / 01 / 06$ & $13: 46: 4$ & $\frac{34.15}{34.12}$ & 45.559 & 10 & $\frac{3.11}{4.40}$ & 169 & $\frac{50}{77}$ & 128 & $\frac{153}{275}$ & 40 & 20 & $\frac{11}{23}$ \\
\hline $2019 / 01 / 06$ & $13: 55: 06$ & 34.134 & 45.576 & 16 & 4.15 & 4 & 58 & 138 & 120 & 55 & 40 & 02 \\
\hline $2019 / 01 / 06$ & 14:15:08 & 34.098 & 45.649 & 19 & 4.62 & 140 & 70 & 75 & 358 & 25 & 125 & 24 \\
\hline
\end{tabular}




\begin{tabular}{|c|c|c|c|c|c|c|c|c|c|c|c|c|c|c|c|c|c|c|c|c|c|}
\hline $2019 / 01 / 06$ & $14: 29: 24$ & 34.114 & 45.597 & 19 & 3.92 & 155 & 80 & 70 & 39 & 22 & 153 & 32 & 262 & 20 & 159 & 51 & 42 & 98 & 8 & 2.5 & TF \\
\hline $2019 / 01 / 14$ & $18: 17: 59$ & 34.112 & 45.618 & 15 & 4.40 & 336 & 72 & 88 & 344 & 18 & 96 & 05 & 27 & 58 & 124 & 31 & 294 & 26 & 116 & 1.5 & $\mathrm{TF}$ \\
\hline $2019 / 01 / 15$ & $0: 56: 21$ & 34.107 & 45.629 & 14 & 3.76 & 135 & 75 & 30 & 36 & 61 & 163 & 09 & 263 & 57 & 159 & 32 & 337 & 76 & 166 & 1.5 & $\mathrm{TF}$ \\
\hline $2019 / 01 / 15$ & 17:07:01 & 34.123 & 45.626 & 14 & 3.71 & 188 & 71 & 137 & 295 & 50 & 25 & 13 & 246 & 44 & 349 & 43 & 144 & 62 & 152 & 1.5 & $\mathrm{TF}$ \\
\hline $2019 / 03 / 12$ & 12:06:06 & 34.243 & 45.580 & 15 & 4.51 & 155 & 59 & 106 & 305 & 35 & 65 & 12 & 323 & 14 & 56 & 71 & 193 & 140 & 50 & 2.5 & $\mathrm{NS}$ \\
\hline $2019 / 04 / 01$ & $10: 07: 24$ & 33.717 & 45.697 & 19 & 4.83 & 347 & 68 & 125 & 105 & 40 & 35 & 16 & 52 & 32 & 153 & 53 & 299 & 46 & 136 & 2.5 & SS \\
\hline $2019 / 04 / 01$ & $10: 16: 14$ & 33.704 & 45.713 & 19 & 4.63 & 324 & 60 & 87 & 150 & 30 & 95 & 15 & 56 & 02 & 326 & 75 & 226 & 57 & 147 & 2.5 & $\mathrm{TF}$ \\
\hline $2019 / 04 / 01$ & $10: 53: 36$ & 33.702 & 45.799 & 17 & 4.20 & 340 & 60 & 125 & 105 & 45 & 45 & 08 & 45 & 30 & 140 & 59 & 301 & 42 & 132 & 2.5 & $\mathrm{TF}$ \\
\hline $2019 / 04 / 15$ & 6:34:31 & 34.507 & 45.731 & 17 & 4.08 & 340 & 80 & 80 & 205 & 14 & 135 & 34 & 79 & 10 & 342 & 54 & 238 & 93 & 3 & 2.5 & $\mathrm{TF}$ \\
\hline $2019 / 05 / 11$ & $10: 28: 58$ & 34.870 & 45.755 & 13 & 4.92 & 12 & 73 & 132 & 120 & 45 & 25 & 17 & 72 & 40 & 177 & 45 & 324 & 66 & 156 & 2.5 & $\mathrm{TF}$ \\
\hline $2019 / 05 / 25$ & $10: 20: 44$ & 34.634 & 46.359 & 19 & 4.35 & 305 & 75 & -50 & 52 & 42 & -157 & 45 & 255 & 38 & 113 & 20 & 06 & 89 & 179 & 0.5 & SS \\
\hline $2019 / 05 / 25$ & $18: 26: 42$ & 34.863 & 45.837 & 18 & 4.01 & 40 & 78 & 144 & 140 & 55 & 15 & 15 & 05 & 52 & 115 & 34 & 265 & 1 & 91 & 1.5 & $\mathrm{TF}$ \\
\hline $2019 / 06 / 05$ & $3: 33: 05$ & 34.419 & 45.603 & 18 & 4.54 & 160 & 70 & 90 & 340 & 20 & 90 & 25 & 250 & 0 & 340 & 65 & 70 & 70 & 160 & 2.5 & $\mathrm{TF}$ \\
\hline $2019 / 06 / 05$ & $3: 36: 16$ & 34.447 & 45.636 & 14 & 4.61 & 172 & 57 & 130 & 295 & 50 & 45 & 04 & 145 & 33 & 238 & 57 & 49 & 144 & 54 & 2.5 & $\mathrm{TF}$ \\
\hline $2019 / 06 / 23$ & $16: 51: 59$ & 34.451 & 45.626 & 18 & 4.43 & 176 & 62 & 112 & 315 & 35 & 55 & 14 & 250 & 19 & 345 & 66 & 125 & 66 & 156 & 2.5 & $\mathrm{TF}$ \\
\hline $2019 / 07 / 17$ & $15: 19: 33$ & 34.452 & 45.614 & 16 & 4.18 & 290 & 60 & 45 & 173 & 52 & 141 & 05 & 50 & 38 & 317 & 52 & 146 & 52 & 142 & 2.5 & $\mathrm{TF}$ \\
\hline $2019 / 07 / 29$ & $20: 47: 10$ & 34.483 & 45.617 & 14 & 4.20 & 335 & 50 & 90 & 155 & 40 & 90 & 05 & 65 & 0 & 155 & 85 & 245 & 65 & 155 & 2.5 & $\mathrm{TF}$ \\
\hline $2019 / 08 / 03$ & $00: 26: 06$ & 34.590 & 46.223 & 17 & 4.02 & 330 & 79 & 139 & 70 & 50 & 15 & 18 & 296 & 48 & 47 & 36 & 142 & 93 & 3 & 2.5 & $\mathrm{TF}$ \\
\hline
\end{tabular}

O. Time (UTC) original time in UTC, Lat latitude in degree, Log longitude in degree, CD calculated depth in km, MW moment magnitude, $\mathrm{S}$ strike, $\mathrm{D}$ dip, $\mathrm{R}$ rake angle, $\mathrm{P}, \mathrm{N}$, and $\mathrm{T}$ compressional, normal, and tensional moment stress axes respectively, PL plunge angle, AZ azimuth. $S H_{M A X}$ and $S H_{\text {min }}$ respectively, maximum and minimum horizontal principal stress directions, SR stress regime according to the WSM standard. R', stress regime index. NS normal faulting with strike-slip component, SS strike-slip faulting, TS thrust faulting with strike slip component, TF thrust faulting, UF unknown or oblique faulting

The small circle on the upper left nook of each panel exhibits the orientation and kind of the horizontal stress axes. The histograms to the lower-left nook of the stereograms portray the rating of the misfit angle F5 in Win-tensor program weighted mathematically in relation to the magnitude for each status. Note that the stress field changes gradually from the compression in the group's AA, BB and CC thrust belt to transpression while, strike slip in group DD respectively, where preexisting NW-SE to NE-SW deep faults system framework is reactivated.

\section{Quality Ranking Scheme Results}

Zoback (1992) has mentioned that the precision of the results increases (higher quality rankings) as the magnitude of the earthquake increase but in the single focal mechanism quality, A or B cannot be given even if the solution is well constrained and the earthquake is large. In this study, we compiled the stress data and it includes 94 data records. Indexes of stress inversion with the quality ranking scheme outcomes for the four sub-regions as in (Table 2).

These were specified to be of B and C quality for the four groups in the study region.

Table 2. Stress inversion for the four sub-regions (parameters of the stress tensor)

\begin{tabular}{|c|c|c|c|c|c|c|c|c|c|c|c|c|c|}
\hline \multicolumn{2}{|c|}{ Circle definition } & \multicolumn{6}{|c|}{ Reduced stress tensor parameters } & \multirow{3}{*}{$\begin{array}{l}\text { stress } \\
\text { ratio } \\
(\mathrm{R})\end{array}$} & \multicolumn{2}{|c|}{$\begin{array}{c}\text { Horizontal stress } \\
\text { axes }\end{array}$} & \multirow{3}{*}{$\begin{array}{l}\text { Quality } \\
\text { Rank } \\
\text { (Q.R) }\end{array}$} & \multirow{3}{*}{$\begin{array}{c}\text { Stress } \\
\text { regime index } \\
\left(R^{\prime}\right)\end{array}$} & \multirow{3}{*}{$\begin{array}{l}\text { Stress } \\
\text { regime }\end{array}$} \\
\hline \multirow[t]{2}{*}{ Group } & \multirow{2}{*}{$\begin{array}{c}\text { No. of } \\
\text { Data }\end{array}$} & \multicolumn{2}{|c|}{$\sigma 1$} & \multicolumn{2}{|c|}{$\sigma 2$} & \multicolumn{2}{|c|}{$\sigma 3$} & & \multirow[t]{2}{*}{$S H_{M A X}$} & \multirow[t]{2}{*}{$S H_{\min }$} & & & \\
\hline & & PL & $\mathbf{A Z}$ & PL & $\mathbf{A Z}$ & PL & $\mathbf{A Z}$ & & & & & & \\
\hline AA & 9 & 01 & 089 & 33 & 180 & 57 & 358 & 0.44 & 089 & 179 & B & 2.44 & $\mathrm{TF}$ \\
\hline BB & 50 & 24 & 244 & 14 & 340 & 62 & 098 & 0.26 & 059 & 149 & B & 2.4 & $\mathrm{TF}$ \\
\hline $\mathrm{CC}$ & 13 & 08 & 240 & 36 & 336 & 53 & 139 & 0.1 & 065 & 155 & $\mathrm{C}$ & 2.47 & TF \\
\hline DD & 22 & 07 & 289 & 83 & 090 & 02 & 199 & 0.54 & 106 & 016 & B & 1.47 & SS \\
\hline
\end{tabular}



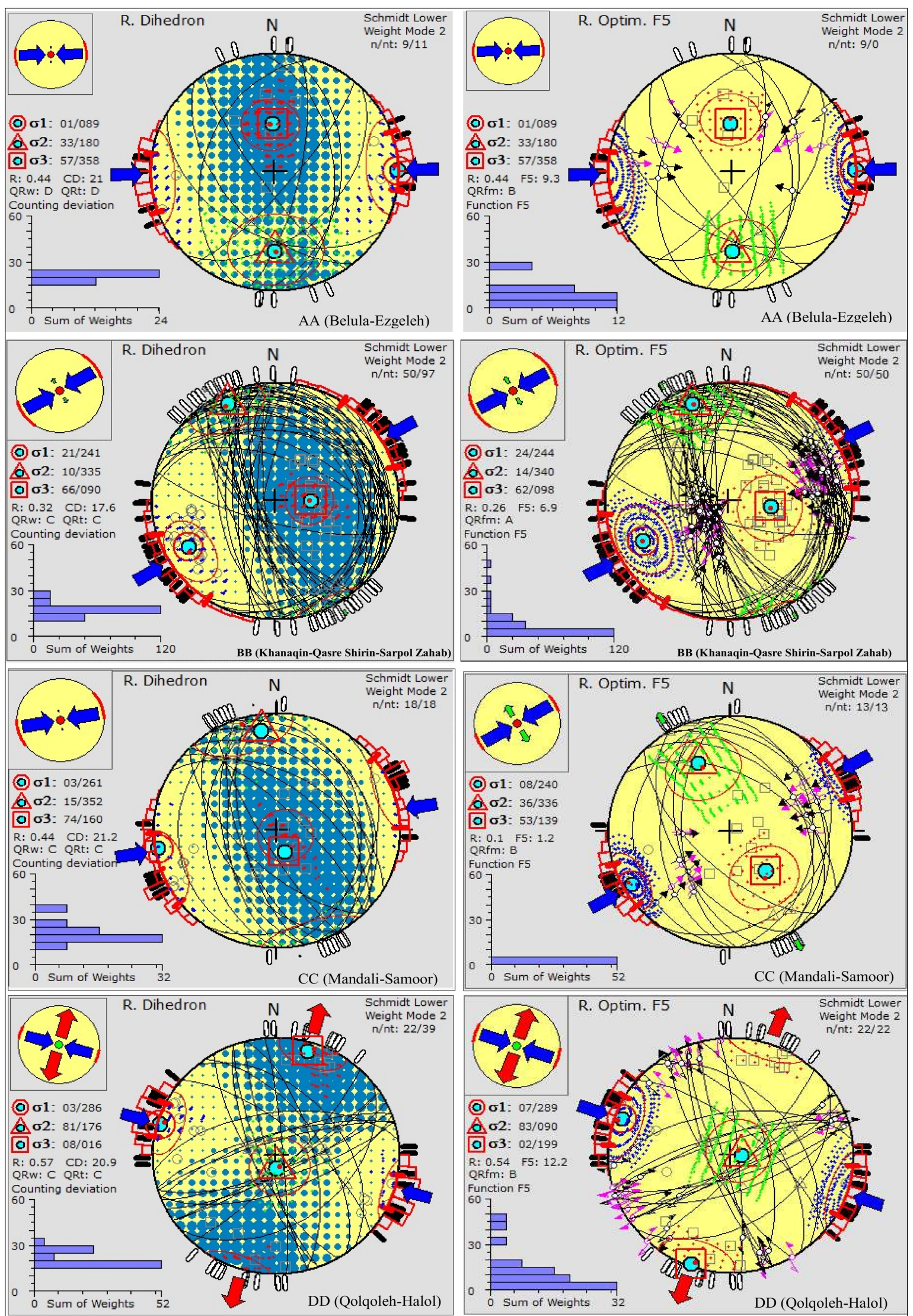

Fig. 6. Formal stress inversion of the focal mechanisms data based on Table (1) and Fig. 1 Results are given in Table (2). The New Right Dihedron method (left panels) and the Rotational Optimization method (right panels) 


\section{DISCUSSION}

Different structural frameworks may be presently undergoing the selfsame stress regime but displaying differences in their focal mechanisms. Defining a small group might produce a spurious impression of stress field variation due to it might also reflect the heterogeneity of the reactivated structures.-Results obtained in the present research reveals the spatial distribution of focal mechanisms, the orientation of the $S H_{M A X}$ and $S H_{\min }$ axes, the focal mechanism types and compare for the homogeneity with lateral differences. Tectonic stress regimes, styles of faulting and tectonic stress fields in each sub region is debated as follow:

\section{Belula-Ezgeleh (Group AA)}

The Northern part of the study region is located on the border of Iraq-Iran within what has known the Zagros fold and thrust belt, which delimits the continental collision zone between the Arabian and Eurasian Plates. There are six events only for this set. The stress tensor indicates that compressive is identical in a nearly horizontal southwestern -northeastern direction (N89 $\pm 14.4 \mathrm{E}$ ), and the collection of thrust with strike-slip faulting is the expression by the comparatively high stress ratio $R^{\prime}(2.44 \pm 0.30)$ (Table 2 ) (Fig. 6), while the axis of the $S H_{\min }$ is in a nearly vertical direction.

\section{Khanaqin-Qasre Shirin-Sarpol Zahab (Group Bb)}

This group represents the largest number of events (45 events), most of them are inside Iran and a few are on the Iraq-Iran border, located within the Zagros fold, thrust belt that is a very seismically active region. A tectonically effective zone that accommodates crustal shortening resulting from the collision between the Arabian and the Eurasian Plates (Berberian and King, 1981) and observes that tectonic movement is divided between various kinds of faults. Due to local structural intricacies, which may demonstrate, why the Qasre Shirin concatenation broke in earthquakes sequence of moderate events Instead of being than as a single thoroughgoing larger rupture with NW striking segments, which parallel the regional orientation in fold axes (Nissen et al., 2019). Reverse faulting with almost all compression axes in the northeastern to southwest orientations characterizes the solutions. The inverted stress field has a $S H_{M A X}$ orientation $(\mathrm{N} 59 \pm 20 \mathrm{E})$, and stress ratio $R^{\prime}(2.4 \pm 0.3)$ (Table 2 ) (Fig. 6),

\section{Mandali-Samoor (Group CC)}

Most of the events in this group are distributed between Iraq and Iran on the border, and few kilometers northeast of the Iranian town of Naft Shahr (Fig.1). The orientation of the direction 
of maximum compressive stress and the prevailing pattern of faulting is northeast-southwest. Thus, the Outputting stress tensor indicates that compression in a northeastern-southwestern orientation $(\mathrm{N} 80 \pm 18.3 \mathrm{E})$. The comparatively high-stress ratio $R^{\prime}(2.47 \pm 0.24)$ with a compressive tectonic system (Table 2) (Fig. 6).

\section{Qolqoleh-Halol (Group DD)}

The Qolqoleh-Halol located in the western part of the study region. Twenty-two seismic events are located inside Iran between high Zagros fault, and main recent fault, which is a major northwestern-southeastern, $800 \mathrm{~km}$ long right lateral strike-slip fault that accommodates some of the strain (Tchalenko and Braud, 1974) (Fig. 2). The strike-slip components in faulting mechanisms can be seen all over the region. All of mechanisms show and reveal a general trend of the $S H_{M A X}$ orientation is nearly a NW-SE orientation $(\mathrm{N} 106 \pm 8.6 \mathrm{E})$ and the relatively stress ratio $R^{\prime}(1.47 \pm 0.11)$ (Table 2) (Fig. 6).

\section{CONCLUSIONS}

The general direction of the $\left(S H_{M A X}\right)$ is northwestern-southeastern to northeasternsouthwestern with the presence of local deviations that are associated with the major geological structures in the region. The compression stress system at the Zagros fold and the thrust zone have a perpendicular direction near the Iraq-Iran border, as shown by the directions of the horizontal stress axes. The presence of five categories of stress regimes are determined by focal mechanisms inversion of the recorded events. The prevailing tectonic systems are TF (50.98 $\%$ ), SS (29.40 \%), and UF (13.70 \%); while the rest of the tectonic systems are less present TS $(4.90 \%)$, and NS $(0.98 \%)$. We note the gradual changes in the stress field, wherein groups AA, $\mathrm{BB}$ and $\mathrm{CC}$ is compression in thrust belt, while, in group DD there is transpression and strikeslip. These changes cause reactivation of the preexisting northwestern-southeastern to northeastern-southwestern deep faults system.

Results obtained in the present research has a good harmony with both seismic trends concluded from earthquake locations and mapped faults and corresponding with the tectonic framework of the Arabian-Eurasian continental collision region. The strike-slip movement on the surfaces of faults appears to be the result of the rotation of the Arabic plate counterclockwise. The spatial differences of the tectonic setting and the stress field are compatible with the neotectonic stress field that is identified from focal mechanism data. The relation obtained between moment and local magnitude was suitable for the researched area within the magnitude range. 


\section{ACKNOWLEDGMENTS}

We, the authors extend sincere thanks to Miroslav Hallo, from the Faculty of Mathematics and Physics, in Charles University, Prague, Czech Republic, for permission to use the MechApp software. We are also grateful to Damin Delvaux of the Royal Museum from Central Africa of Belgium for a permit to use the Windows-Tensor software. We can only give our thanks to Tiesheng $\mathrm{Wu}$, Hainan Research Center of Engineering Earthquake for using his tool's ArcBeachBalls-v2.3. The authors are very grateful to the editor in chief Prof. Dr. Salih M. Awadh, the secretary of Journal Mr.Samir R. Hijab. and head of the technical editors Dr. Heba S. Al-Mimar for their great efforts and valuable comments.

\section{REFERENCES}

Abdulnaby, W., 2018. Structural geology and neotectonics of Iraq, Northwest Zagros. In Developments in Structural Geology and Tectonics, 3:53-73.

Abdulnaby, W., Mahdi, H., Al-Shukri, H., and Numan, N. M., 2014. Stress patterns in Northern Iraq and surrounding regions from formal stress inversion of earthquake focal mechanism solutions. Pure and Applied Geophysics, 171(9): 2137-2153.

Abdulnaby, W., Al-Mohmed, R., and Mahdi, M., 2016. Seismicity and recent stress regime of Diyala City, IraqIran border. Modeling Earth Systems and Environment, 2(3):142.

Alridha, N. A. Mohammed, H. J., and Jasim, N. A, 2017. Seismotectonic study of middle and southern Iraq. Iraqi Geological Journal, 50 (2): 24 - 36.

Anderson, E. M., 1951. The Dynamics of Faulting and Dyke Formation with Applications to Britain. Oliver and Boyd, Edinburgh, 206 p.

Angelier, J., and Mechler, P., 1977. Su rune methode graphique de recherch e des contraintes principales egalement utilisable en tectonique et en seismologie: la methode des di edresdroits. Bulletin de la Soci et e $\mathrm{G}$ eologique de France, 7 (19):1309-1318.

Angelier, J., 2002. Détermination du tenseur des contraintes par inversion de mécanismes au foyer de séismes sans choix de plans nodaux, C. R. Geosci., 334(1): 73-80.

Angelier, J., 1984. Tectonic analysis of fault slip data sets. Journal of Geophysical Research, 89: 5835-5848.

Alavi, M., 2004. Regional stratigraphy of the Zagros Fold-thrust belt of Iran and its pro-foreland evolution. American Journal of Science, 304: 1-20.

Barth, A., Reinecker, J., and Heidbach, O., 2008. Stress derivation from earthquake focal mechanisms. World Stress Map Project Guidelines, 12.

Berberian, M., and King, G. C. P., 1981. Towards a paleogeography and tectonic evolution of Iran. Canadian Journal of Earth Sciences, 18(2): 210-265.

Delvaux, D., Moeys, R., Stapel, G., Petit, C., Levi, K., Miroshnichenko, A., Ruzhich, V., Sankov, V., 1997. Paleostress reconstructions and geodynamics of the Baikal region, Central Asia. Part II: Cenozoic rifting. In: Cloetingh, S., Fernandez, M., Munoz, J.A., Sassi, W., Horvath, F. (Eds.), Structural Controls on Sedimentary Basin Formation: Tectonophysics, 282.

Delvaux, D., and Sperner, B., 2003. Stress tensor inversion from fault kinematic indicators and focal mechanism data: the TENSOR program. In: Nieuwland, D. (Ed.), New Insights into Structural Interpretation and Modelling, Geological Society London, 212: 75e100.

Farzipour, S, A., Yassaghi, A., Sherkati, S. and Koyi, H., 2009. Basin evolution of the Lurestan Region in the Zagros fold-and-thrust belt, Iran. Journal of PetroleumGeology, 32 (1): 5 - 20.

Fouad, S. F., 2014. Western Zagros fold - thrust bekt, Part II. In: The geology of the high folded zone. Iraqi Bull Geology Mining, Special Issue, 6: $57-75$.

Fouad, S. F., 2015. Tectonic map of Iraq, scale 1: 1000 000, 3rd ed. Iraqi Bull. Geology Mining, 11 (1): 1-7.

Frohlich, C., 1992. Triangle diagrams: ternary graphs to display similarity and diversity of earthquake focal mechanisms, Physics of the Earth and Planetary Interiors, 75: 193-198. 
Gephart, J. W., Forsyth, D. W., 1984. An improved method for determining the regional stress tensor using earthquake focal mechanism data: application to the San Fernando earthquake sequence. Journal of Geophysics, Res. 89 (B11): 9305-9320.

Hallo, M., Opršal, I., Asano, K., and Gallovič, F., 2019. Seismotectonics of the 2018 northern Osaka M6.1 earthquake and its aftershocks: joint movements on strike-slip and reverse faults in inland Japan. Earth, Planets and Space, 71(1): 1-21.

Heidbach, O., Tingay, M., Barth, A., Reinecker, J., Kurfeß, D., Müller, B., 2010. Global spatial wavelength analysis of the tectonic intraplate stress pattern. Tectonophysics, 482: 3e15.

Heidbach, O., 2016. Scientific Technical Report 16-01: WSM Quality Ranking Scheme, Database and Analysis Guidelines for Stress Indicators.

Heidbach, O., Rajabi, M., Reiter, K., Ziegler, M., and WSM team, 2016. World Stress Map Database Release. V. 1.1. GFZ Data Services. http://doi.org/10.5880/WSM.2016.001

Jackson, J., R. Norris and Youngson, J., 1996. The structural evolution of active fault and fold systems in central Otago, New Zealand: Evidence revealed by drainage patterns. Journal of Structural Geology,18:217-234.

Jassim, S. Z., and Goff, J. C., 2006. Geology of Iraq. (Eds.) DOLIN, sro, distributed by Geological Society of London.

Khodaverdian, A., Zafarani, H., and Rahimian, M., 2015. Long-term fault slip rates, distributed deformation rates and forecast of seismicity in the Iranian Plateau. Tectonics, 34(10): 2190-2220.

Lund, B., and Townend, J., 2007. Calculating horizontal stress orientations with full or partial Knowledge of the tectonic stress tensor. Geophysics Journal International, 270: 1328e1335.

Mobasher, K., 2007. Kinematic and tectonic significance of the fold and fault related fracture systems in the Zagros

Mountains, Southern Iran, Ph.D. thesis, Georgia State University, USA, 123 p.

Mohammed, H., Jasim., and Al-Rahim, A. M., 2020. Seismotectonics and source parameters of the mid-eastern Iraq - western part of Iran from moment tensor inversion (Under publication) .

Michael, A. J., 1984. Determination of stress from slip data: faults and folds. Journal Geophysics Resource, 89(B13):11517-11526.

Nissen, E., Ghods, A., Karasözen, E., Elliott, J. R., Barnhart, W. D., Bergman, E. A., and Abdulnaby, W., 2019. The 12 November 2017 M w 7.3 Ezgeleh-Sarpolzahab (Iran) Earthquake and Active Tectonics of the Lurestan Arc. Journal of Geophysical Research: Solid Earth, 124(2): 2124-2152

Scholtz, C. H., 2002. The mechanics of earthquakes and faulting. Cambridge University Press, 2nd edition, 471P.

Sissakian, V. K., 2000. Geological Map of Iraq, 3 rd edit., scale 1: 1000 000. GEOSURV, Baghdad, Iraq.

Sissakian, V., Al-Ansari, N., and Knutsson, S., 2014. Origin of some transversal linear features of NE-SW trend in Iraq, and their geological characters. Natural Science, 6(12): 996-1011.

Stein, S., and Wysession, M., 2003. An introduction to seismology, earthquakes, and earth structure, Blackwell Publishing, 3rd edition, 498P.

Tchalenko, J. S., and Braud, J., 1974. Seismicity and structure of the Zagros (Iran): the Main Recent Fault between 33 and 35 N. Philosophical Transactions of the Royal Society of London. Series A, Mathematical and Physical Sciences, 277(1262):1-25.

Vavryčuk, V., 2014. Iterative joint inversion for stress and fault orientations from focal mechanisms. Geophys J Int 199(1):69-77. https://doi.org/10.1093/gji/ggu224.

Zebari, M., Grützner, C., Navabpour, P., and Ustaszewski, K., 2019. Relative timing of uplift along the Zagros Mountain Front Flexure (Kurdistan Region of Iraq): Constrained by geomorphic indices and landscape evolution modeling. Solid Earth, 10(3): 663-682.

Zoback, M. L., 1992a. First- and second-order patterns of stress in the lithosphere: the world stress map project. Journal Geophysics Resource, 97 (B8): 11703e11728.

Zoback, M. L., 1992b. Stress field constraints on intraplate seismicity in eastern North America. Journal Geophysics Resource, 97 (B8): 11761e11782. 